Journal of Sustainamle Agricultural Sciences http://jsas.journals.ekb.eg/

\title{
Milk Yield, Productive and Reproductive Performance of Rabbit Does Fed Different Levels of Arabic Gum in Diet
}

\author{
Kh. Amber ${ }^{1}$, Neamt A. Badawy ${ }^{1}$, W.A. Morsy ${ }^{2 *}$ and Shereen M. El-Desoukey ${ }^{2}$ \\ ${ }^{1}$ Dept. of Poultry Production, Fac. of Agric., Kafr El-Sheikh Univ., Egypt \\ ${ }^{2}$ Animal Production Research Inst., Agric. Research Center, Dokki, Giza, Egypt
}

\begin{abstract}
$\mathbf{T}$ HE EFFECTS of Gum Arabic (GA) supplementation in the diet of rabbit does in several physiological states on milk composition, productive and reproductive performance were assessed. Twenty eight Baladi Black rabbit does ( 7 does per treatment) of about 8-9 months of age with an average live body weight of $3449 \pm r 1,7) \mathrm{g}$, were used. Animals were fed the basal diet supplemented with 0 (control), 0.5, 1 and $1.5 \%$ Gum Arabic of the diet. Results revealed that the milk yield (MY, g) increased $(\mathrm{P}<0.01)$ by 3.5, 4.9 and $7.7 \%$ in rabbit does fed diet containing $0.5,1$ and $1.5 \%$ Gum Arabic, respectively, as compared with those fed control diet. Also, letter size at weaning was significantly higher with rabbit fed Gum Arabic in diets than those fed control diet. Mortality rate of the pups during lactation period was higher with control diet compared to diet supplemented with $0.5,1$ and $1.5 \%$ Gum Arabic (4.90 vs. $1.83 \% ; \mathrm{P}<0.01$, as average). The best value of relative revenue was found in the rabbits fed diet containing $1 \%$ Gum Arabic (113\%), while the poorest value was recorded with those fed control diet (100\%). Conclusively, the present study suggested that supplementing 1 or $1.5 \%$ Gum Arabic in rabbit does diet significantly improve productive and reproductive performance of rabbits does during pregnancy and lactation periods and minimal mortality of kits. From the economic point of view, $1 \% \mathrm{GA}$ is recommended for rabbit does diets, which showed the best results.
\end{abstract}

Keywords: Gum Arabic, Rabbit, Does, Productive, Reproductive, Mortality, Milk, Economic.

\section{Introduction}

Rabbit does are nursing their kits until weaning age (4-5 weeks of age). Kits until 18-19 days of age only feed their mother's milk (Fortun-Lamothe et al., 2000). Rabbits kit needs high energy milk and have low thermal isolation. Therefore, rabbits kit mortality and growth performances are depending on the quantity and quality of the milk suckling (Szendrö and Maertens, 2001). Consequently, milk yield (MY) has a great importance in does performance. When rabbit strains were selected for increased litter size, weaning weight of kits depressed (Rochambeau, 1998). This indicates that the MY improvement was not harmonious with those of litter size, which causing reduction in milk available per kit (Szendrö and Maertens, 2001). Studies have shown that MY of rabbit does is strongly influenced by diet composition
(Pascual et al., 2002 and Maertens et al., 2006). During lactation, the doe's body is subjected to a marked reduction in energy reserves following the mobilization of fat deposits (Xiccato et al., 2004). This energy loss remains constant throughout lactation (Parigi Bini et al., 1990) and no recovery is observed during the final phase due to the milk energy output, which remains high even after 25 30 days of lactation. The simultaneous condition of pregnancy is responsible for a further reduction in fat content and body energy levels. It prevents the return to normal body conditions (Xiccato et al., 2005) and increases protein requirements in response to the elevated demand for protein by the fetuses and the rapid turnover of fetal protein (Xiccato et al., 1995). A little importance has been given to the goal of increasing voluntary feed intake and maintaining the body condition of the females (Theilgaard et al., 2007). 
Gum Arabic (GA) is a dried exudate obtained from the branches and stems of Acacia senegal and closely related species (FAO, 1999). It is a complex polysaccharide of high molecular weight, which contains neutral sugars as rhamnose, arabinose and galactose; in addition to acids such as glucuronic acid and also minerals such as calcium, magnesium, potassium, sodium and phosphorous (Tylor et al., 1981 and Osman, 1993). Gum Arabic has wide industrial utilizes such as in food industry (stabilizer, thickening agent and emulsifier), textile, pottery, lithography, cosmetics and pharmaceutical industries (Verbeken et al., 2003). Also, Gum Arabic has been successfully used for inflammation treatment of the intestinal mucosa and externally to cover inflamed surfaces (Gamal El-Din et al., 2003). Moreover, Gum Arabic has anti-oxidant, nephro-protecting effects (Ali et al., 2008). El-khier et al. (2010) found that laying hens fed gum Arabic (1\%) in diet increased feed intake, as compared to control and also significantly increased albumin, $\mathrm{Ca}$ and $\mathrm{P}$ in blood serum. Moreover, Abd Razig et al. (2010) observed that the performance (bodyweight egg and daily egg production) of laying hens showed significant increase with increasing dietary levels of Gum Arabic (0.1, 0.3, 0.5 and 1\%). Also, Tag El-Din et al. (2018) observed that supplementing $0.25 \%$ citric acid salt by alone or in the combination with $0.05 \%$ probiotic (Bioplus) to broiler diets might be used to improve growth performance and physiological status as well as economic efficiency during the fattening period.

Therefore, this study was carried out to evaluate the effects of different levels of Gum Arabic in diets on milk production, productive and reproductive performance of rabbit does.

\section{Materials And Methods}

The experiments were performed at the Rabbits Farm of Sakha Station, Animal Production Research Institute, Agriculture Research Center, Egypt. Twenty eight Baladi Black rabbit does about 8-9 months of age with an average live body weight of $3449 \mathrm{~g}$, were used during the period from $1^{\text {st }}$ January to $30^{\text {th }}$ May 2018. Four experimental treatments were used 7 does per each. Animals were fed the basal diet containing 0 (control), 0.5, 1 and 1.5\% Gum Arabic of the diet. All diets were formulated according to De Blas and Mateos (1998), containing all the essential nutrients requirements for rabbit does. Gum Arabic chemical composition is $87 \% \mathrm{DM}, 3.71 \% \mathrm{CP}, 0.43 \%$ $\mathrm{EE}, 2.73 \%$ ash and $3000 \mathrm{kcal} / \mathrm{kg} \mathrm{DE}$, according to Amber et al. (2017).
The sex ratio was 3: 1 female to male throughout the experiment. Lighting program during the experiment was 16 hours light and 8 hours dark. Mating system was presented rabbit doe to male after parturition at 7 days. Rabbit does were tested for pregnancy by abdominal palpation at ten days after mating. Non-pregnant rabbit does were re-mated. Housing system was individual cages provided with feeders, automatic nipple drinkers and nest boxes.

The milk production experiment was carried out on twenty lactating rabbit does (five per every experimental treatment). Rabbit does were separated from their pups after parturition. During lactation, eight kits were kept constant and dead kits were replaced daily by pups of a similar weight, age and treatment provided from nurse does. Rabbit does daily weight loss after suckling was used to calculate milk yield (MY, g). Rabbit does were allocated in a different cage to prevent free nursing. Suckling allowed once a day, at $09.00 \mathrm{AM}$ in the nest box, for only 8 to 10 minutes. Rabbit does daily feed intake and litters weekly weight were recorded. On the 21 st day of lactation, suckling kits ate the same diet like their mother and weaned at 30 days of age.

Analyses of variance were performed on data, using the General Linear GLM Procedure of SAS program (SAS, Institute, Inc., 2003). The application of the least significant ranges among the different treatment means was performed (Duncan, 1955).

\section{Results And Discussion}

\section{Milk production}

Data of Fig. 1 and 2 show the effect of Gum Arabic supplementation on milk production. The dietary Gum Arabic level had a significant effect on milk production; resulting in higher values for rabbit does fed diets with different Gum Arabic levels than those fed the control diet. The milk yield significantly $(\mathrm{P}<0.001)$ increased by 3.5, 4.9 and $7.7 \%$ in rabbit does fed 0.5 , 1and $1.5 \%$ Gum Arabic of the diet, respectively, as compared with those fed a basal diet (Fig. 2). Values of milk yield observed here were higher than those obtained by Ashour et al. (2016), who found that milk yield of baladi black was $113.8 \mathrm{~g}$. The increase of milk yield may be due to the higher feed intake of rabbit does. Milk production was increased by increasing dietary Gum Arabic level throughout the lactation period. 
TABLE 1. Ingredients and chemical analysis of the experimental diets

\begin{tabular}{|c|c|c|c|c|}
\hline \multirow{2}{*}{ Ingredient } & \multirow{2}{*}{ Control } & \multicolumn{3}{|c|}{ Gum Arabic level (\%) } \\
\hline & & 0.5 & 1.0 & 1.5 \\
\hline Barseem hay & 30.0 & 30.3 & 30.5 & 30.8 \\
\hline Barley & 30.0 & 30.0 & 30.0 & 30.0 \\
\hline Soybean meal (44\%) & 19.8 & 20.1 & 20.3 & 20.6 \\
\hline Wheat bran & 16.4 & 15.3 & 14.4 & 13.3 \\
\hline Gum Arabic & 0 & 0.5 & 1 & 1.5 \\
\hline Limestone & 0.6 & 0.6 & 0.6 & 0.6 \\
\hline Di-calcuim & 2.2 & 2.2 & 2.2 & 2.2 \\
\hline Methionine & 0.2 & 0.2 & 0.2 & 0.2 \\
\hline Salt & 0.3 & 0.3 & 0.3 & 0.3 \\
\hline $\operatorname{Premix}^{(1)}$ & 0.3 & 0.3 & 0.3 & 0.3 \\
\hline Anti-fungi & 0.1 & 0.1 & 0.1 & 0.1 \\
\hline Ati-coccidia & 0.1 & 0.1 & 0.1 & 0.1 \\
\hline Total & 100 & 100 & 100 & 100 \\
\hline \multicolumn{5}{|l|}{ Chemical analysis (\%): } \\
\hline Dry matter & 85.83 & 85.84 & 85.84 & 85.85 \\
\hline Ash & 5.53 & 5.54 & 5.54 & 5.55 \\
\hline Crude protein & 18.00 & 18.02 & 18.01 & 18.02 \\
\hline Ether extract & 1.58 & 1.56 & 1.53 & 1.49 \\
\hline Crude fiber & 13.37 & 13.38 & 13.37 & 13.38 \\
\hline Lysine $^{(2)}$ & 0.91 & 0.92 & 0.92 & 0.92 \\
\hline Methionine $^{(2)}$ & 0.46 & 0.46 & 0.46 & 0.46 \\
\hline Calcium $^{(2)}$ & 1.22 & 1.22 & 1.22 & 1.23 \\
\hline Phosphorus $^{(2)}$ & 0.89 & 0.88 & 0.87 & 0.87 \\
\hline Digestible energy $(\mathrm{kcal} / \mathrm{kg})^{(2)}$ & 2452.6 & 2455 & 2457.4 & 2459.8 \\
\hline Metabolizable energy $(\mathrm{kcal} / \mathrm{kg})^{(2)}$ & 2291.1 & 2293.4 & 2296 & 2298.2 \\
\hline
\end{tabular}

1- One kilogram of mineral-vitamin premix provided: Vitamin A, 150,000 UI; Vitamin E, $100 \mathrm{mg}$; Vitamin K3, 21mg; Vitamin B1, 10 mg; VitaminB2, 40mg; Vitamin B6, 15mg; Pantothenic acid, $100 \mathrm{mg}$; Vitamin B12, 0.1mg; Niacin, $200 \mathrm{mg}$; Folic acid, 10mg; Biotin, 0.5mg; Choline chloride, $5000 \mathrm{mg}$; Fe, 0.3mg; Mn, $600 \mathrm{mg}$; Cu, 50 mg; Co, $2 \mathrm{mg}$; Se, $1 \mathrm{mg}$; and Zn, 450mg.

2- Calculated according to De Blas and Mateos (1998).
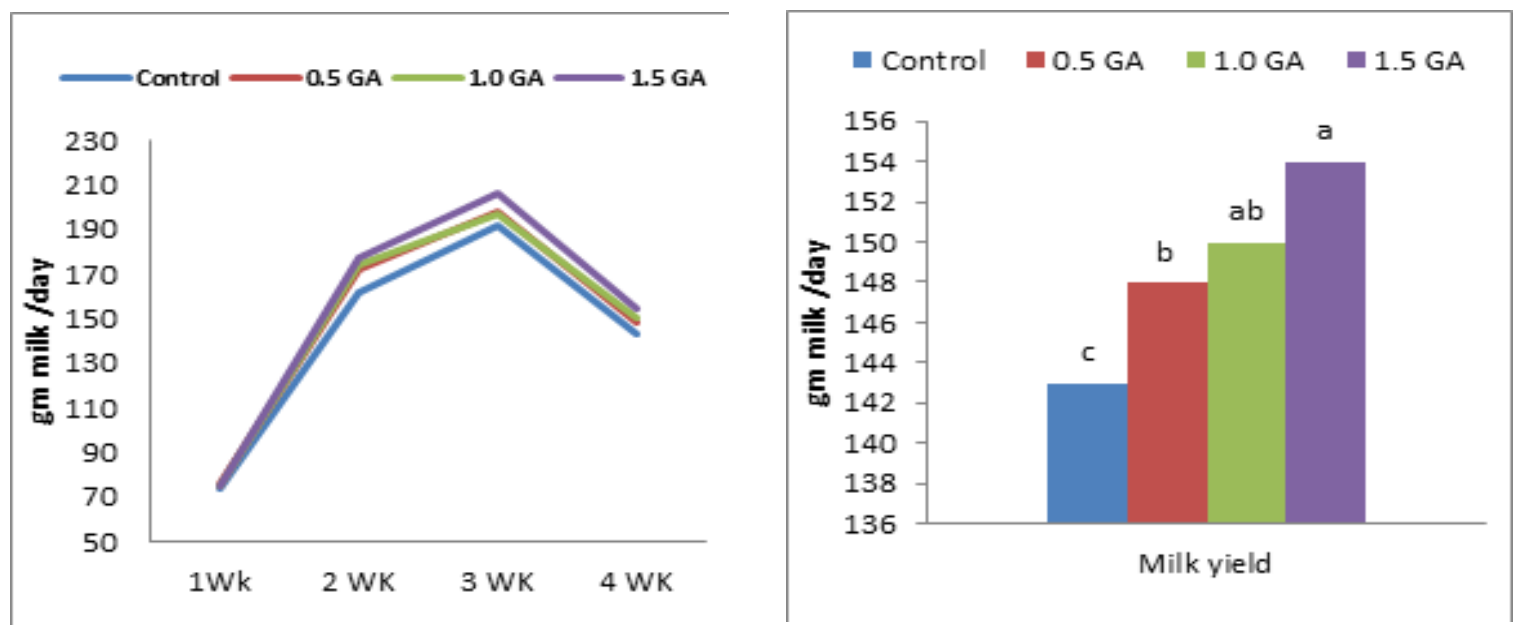

Fig. 1. Effect of dietary Gum Arabic level on milk production Fig. 2. Effect of dietary Gum Arabic level on milk yield 
In this respect, Amber et al. (2017) found that, adding Gum Arabic to the rabbit diet caused an increase of feed efficiency. This may lead to increase milk production and secretion in treating rabbits. Moreover, litter size at birth improved as a result of increasing in milk production (Table 3 ), where there was a positive correlation between the litter size at birth and milk yield (Lebas et al., 1997 and Rommers et al., 2001).

\section{Productive and reproductive performance}

The effects of experimental treatments on the reproductive and productive performance are shown in Tables 2 and 3. It is clear that no significant differences in the live body weight of rabbit does at mating, partum and pre-partum except for weaning, which significantly increased by increasing the level of Gum Arabic in the diet. Does weight gain at gestation significantly increased $(\mathrm{P}<0.001)$ with increasing dietary Gum Arabic supplementation. Pregnant rabbit does given diet containing 1.5\% Gum Arabic showed the highest weight gain than those fed other dietary Gum Arabic levels during the pregnancy period. The pregnancy weight gain increase mainly due to foetal growth (Parigi Bini et al., 1991). Lactation rabbit does weight decreased about 101-145 g, which was about $3.42 \%$ (as an average) of their initial live body weight with low losses for rabbit does fed diets containing 1 or $1.5 \%$ Gum Arabic of the diet. The balance of fat and energy are negative in lactating rabbit does (Xiccato, 1996). Daily feed intake of pregnant rabbit does did not significantly affect by dietary Gum Arabic. While, daily feed intake of lactating rabbit does increased $(\mathrm{P}<0.05)$ with increasing dietary Gum Arabic level, where rabbit does fed diets containing 1 and $1.5 \%$ Gum Arabic achieved the highest values. Moreover, daily feed intake of kits in the period from 22 day of age until weaning increased $(\mathrm{P}<0.05)$ as the level of Gum Arabic increased (Table 3). The increase of feed intake during the lactation period compared to that of gestation phase was lower as compared to reported values of $80-90 \%$ in the literature (Lebas, 1984); this is probably due to higher ambient temperature during lactation period than that in the literature, resulting in lower feed intake by rabbit does (Prasad and Karim, 1998).

The dietary Gum Arabic level had a significant effect on the milk conversion ratio during the first week of lactation (Table 3). During the second and third weeks of lactation period, no significant differences could be observed among the experimental groups. An increase in the dietary Gum Arabic level increased $(\mathrm{P}<0.05)$ feed intake of kits in the last 9 days of the lactation period. Litters fed control diet seemed to compensate for the lower amount of milk available to them with a lower feed intake. Both size and weight of litters at the birth, 21 days and weaning (30 days) were affected by supplementing dietary Gum Arabic (Table 3). Also, letter size at weaning was significantly higher with rabbit fed Gum Arabic in diets than those fed control diet (6.33 vs. 7.07; $\mathrm{P}<0.001$, as average). The improvement in litter traits proved that, the Gum Arabic may be capable to improve the milking ability of the rabbit does which is reflected in her care and ability to suckle her young till weaning.

TABLE 2. Effect of dietary Gum Arabic level on performance of does during gestation and lactation periods of rabbits.

\begin{tabular}{|c|c|c|c|c|c|c|}
\hline \multirow{2}{*}{ Item } & \multirow{2}{*}{ Control } & \multicolumn{3}{|c|}{ Gum Arabic level (\%) } & \multirow{2}{*}{ SEM } & \multirow{2}{*}{ Sig. } \\
\hline & & 0.5 & 1.0 & 1.5 & & \\
\hline \multicolumn{7}{|l|}{ Does weight (g) at: } \\
\hline Mating & 3451 & 3442 & 3453 & 3448 & 31.61 & NS \\
\hline Pre-Partum & 3760 & 3784 & 3833 & 3849 & 30.82 & NS \\
\hline Partum & 3439 & 3460 & 3492 & 3510 & 29.96 & NS \\
\hline Weaning & $3294 b$ & $3337 \mathrm{ab}$ & $3385 a$ & $3409 a$ & 28.41 & $*$ \\
\hline \multicolumn{7}{|l|}{ Does weight gain (g) at: } \\
\hline Gestation & $309 d$ & $342 \mathrm{c}$ & $380 \mathrm{~b}$ & $400 \mathrm{a}$ & 6.419 & $* * *$ \\
\hline Lactation & $-145 c$ & $-123 b$ & $-107 \mathrm{a}$ & $-101 \mathrm{a}$ & 2.330 & $* * *$ \\
\hline \multicolumn{7}{|l|}{ Feed intake $(\mathrm{g} / \mathrm{d})$ for: } \\
\hline Pregnant does & 162 & 163 & 167 & 171 & 9.758 & NS \\
\hline Lactating does & $204 b$ & $216 a b$ & $220 \mathrm{a}$ & $223 a$ & 4.682 & $*$ \\
\hline
\end{tabular}

Sig.= Significance, ${ }^{* * *}:$ Significant at $0.1 \%$ level of probability, ${ }^{* *}:$ Significant at $1 \%$ level of probability, ${ }^{*}:$ Significant at $5 \%$ level of probability, NS: Non-significant

Means within the same row bearing different letter superscripts $(a, b, c)$ are significantly different $(\mathrm{P} \leq 0.05)$

$\mathrm{SEM}=$ Standard error means.

J. Sus. Agric. Sci. Vol. 46, No. 2 (2020) 
The mortality rate of the pups during the lactation period was higher in the control diet compared to diets with $0.5,1$ and $1.5 \%$ Gum Arabic (4.90 vs. $1.96,2.26$ and $1.28 \% ; \mathrm{P}<0.05$, respectively), which could be due to a lower milk yield of rabbit does. This reduction in mortality rate may be attributed to Gum Arabic has been shown in displays antimicrobial activity and to stimulate intestinal absorption thus counteracting diarrhoea (Ali et al., 2009). These results are in accordance with Amber et al. (2017), who found that the concentration of $(0.5,1$ and 1.5 $\%)$ of Gum Arabic in the diet of growing rabbits decreased mortality rate by $44.4 \%$ (As average), as compared with the control diet. They observed also, rabbits received $1.5 \%$ Gum Arabic diet had significantly the lowest mortality during the experimental period, as compared with those received the control treatment $(5 \%$ vs. $15 \%$, respectively).

During the first three weeks, the weight gain of young rabbit was influenced by milk production, where higher litter weight for diet containing Gum Arabic than for control diet. Moreover, rabbit does fed 1 and 1.5\% Gum Arabic of the diets had significantly higher litters weights, as compared with those fed control diet, during the first three weeks. This was observed also at weaning. Similarly, Fouda and Ismail, (2018) observed that Gum Arabic addition significantly increased litter size, bunny and litter weights at birth and weaning, but overall of all reproductive traits and litter characteristics were better at $2^{\text {nd }}$ and $3^{\text {rd }}$ than at the $1^{\text {st }}$ litter.

TABLE 3. Effect of dietary Gum Arabic level on the performance of litter until weaning of rabbits

\begin{tabular}{|c|c|c|c|c|c|c|}
\hline \multirow{2}{*}{ Item } & \multirow{2}{*}{ Control } & \multicolumn{3}{|c|}{ Gum Arabic level (\%) } & \multirow{2}{*}{ SEM } & \multirow{2}{*}{ P-value } \\
\hline & & 0.5 & 1.0 & 1.5 & & \\
\hline \multicolumn{7}{|l|}{ Litter size at: } \\
\hline Birth (alive) & $6.67 b$ & $7.00 \mathrm{ab}$ & $7.33 \mathrm{a}$ & $7.33 \mathrm{a}$ & 0.169 & $*$ \\
\hline 21 days & $6.33 b$ & $6.86 \mathrm{a}$ & $7.14 \mathrm{a}$ & $7.24 \mathrm{a}$ & 0.173 & $* * *$ \\
\hline Weaning (30day) & $6.33 b$ & $6.86 \mathrm{a}$ & $7.12 \mathrm{a}$ & $7.24 \mathrm{a}$ & 0.136 & $* * *$ \\
\hline \multicolumn{7}{|l|}{ Mortality rate (\%) at: } \\
\hline Birth - 21 day & $4.90 \mathrm{a}$ & $1.96 \mathrm{ab}$ & $2.25 \mathrm{ab}$ & $1.28 \mathrm{~b}$ & 1.074 & $*$ \\
\hline Birth - Weaning & $4.90 \mathrm{a}$ & $1.96 \mathrm{ab}$ & $2.25 \mathrm{ab}$ & $1.28 \mathrm{~b}$ & 1.039 & $*$ \\
\hline \multicolumn{7}{|l|}{ Litter weight (g) at: } \\
\hline Birth & 331 & 334 & 342 & 336 & 5.055 & NS \\
\hline 7th day & $863 \mathrm{c}$ & $895 b$ & $909 \mathrm{ab}$ & $922 \mathrm{a}$ & 8.860 & $* * *$ \\
\hline 14th day & $1446 \mathrm{c}$ & $1497 b$ & $1530 \mathrm{ab}$ & $1546 \mathrm{a}$ & 11.36 & $* * *$ \\
\hline 21 st day & $1907 \mathrm{c}$ & $1984 b$ & $2041 \mathrm{a}$ & $2072 a$ & 14.83 & $* * *$ \\
\hline Weaning (30 day) & $2752 \mathrm{c}$ & $3021 b$ & $3244 a$ & $3329 a$ & 40.85 & $* * *$ \\
\hline Kit individual BW (g) & $4390 \mathrm{~b}$ & $443.9 \mathrm{ab}$ & $455.3 \mathrm{ab}$ & $461.4 \mathrm{a}$ & 5.255 & $*$ \\
\hline $\begin{array}{l}\text { Growth rate of kits (\%) } \\
\text { (21day-weaning) }\end{array}$ & $36.2 \mathrm{c}$ & $41.3 b$ & $45.4 \mathrm{a}$ & $46.4 \mathrm{a}$ & 1.276 & $* * *$ \\
\hline \multicolumn{7}{|c|}{ Milk conversion rate $(\mathrm{g} / \mathrm{g})$ at $(1)$ : } \\
\hline 1st week & $0.98 \mathrm{a}$ & $0.95 \mathrm{ab}$ & $0.93 \mathrm{ab}$ & $0.90 b$ & 0.023 & $*$ \\
\hline 2nd week & 1.96 & 2.01 & 1.96 & 1.99 & 0.047 & NS \\
\hline 3rd week & 2.96 & 2.87 & 2.74 & 2.76 & 0.073 & NS \\
\hline Kits (22-30 day) DFI (g/d) & $163.5 b$ & $172.5 \mathrm{ab}$ & $175.7 \mathrm{a}$ & $178.2 \mathrm{a}$ & 3.919 & $*$ \\
\hline
\end{tabular}

Sig. = Significance, ${ }^{* * *}$ :Significant at $0.1 \%$ level of probability, ${ }^{* *}:$ Significant at $1 \%$ level of probability, ${ }^{*}:$ Significant at $5 \%$ level of probability, NS: Non-significant

Means within the same row bearing different letter superscripts $(\mathrm{a}, \mathrm{b}, \mathrm{c})$ are significantly different $(\mathrm{P} \leq 0.05)$

SEM $=$ Standard error means.

(1) As milk intake of litter (g) per litter weight gain (g) 
The growth rate of pups during the period from 21 days of age until weaning tended to increase with increasing the level of Gum Arabic in diet and the best value was obtained with the higher dietary Gum Arabic level (1 and $1.5 \%$ ). Gum Arabic might improve litter performance by increasing milk production.

\section{Relative revenue}

Data in Table 4 revealed that the total feed cost increased by increasing levels of Gum Arabic in diets, as a result of increasing of feed intake. However, the selling price was increased by increasing dietary Gum Arabic level, as a result of increasing of average weight gain ( $\mathrm{kg} / \mathrm{head})$. The same trend was found in the net revenue and relative revenue, which were increased, as the Gum Arabic level increased in the diets. The best value of relative revenue was found in the rabbits fed diet containing 1\% Gum Arabic (113\%), followed by those fed diet containing $0.5 \%$ Gum Arabic (108\%), but the poorest value was recorded with those fed control diet (100\%). Similarity, Amber et al. (2017) reported that the values of economic efficiency improved with gum Arabic supplementation in rabbit diets, whereas the best value of relative revenue was found in the rabbits received $1.0 \%$ GA diet the $(112.6 \%)$, followed by those received $1.5 \%$ GA diet $(110.9 \%)$, but the poorest value was recorded for the control group (100\%). Also, Amber et al. (2018) observed that under heat stress, raising rabbits in cages with low density and supplementing of $1 \%$ lycopene in diet gave the best productive performance and improving economic efficiency.

TABLE 4. Effect of dietary Gum Arabic level on relative revenue of rabbit does

\begin{tabular}{lcccc} 
& \multicolumn{1}{c}{ Item } & Control & \multicolumn{3}{c}{ Gum Arabic level (\%) } \\
\cline { 4 - 6 } & & $\mathbf{0 . 5}$ & $\mathbf{1 . 0}$ & $\mathbf{1 . 5}$ \\
\hline Total feed intake (kg)* & 12.461 & 12.900 & 13.189 & 13.423 \\
Price /kg diet (L.E.) & 4.60 & 4.93 & 5.27 & 5.60 \\
Total feed cost (L.E.) & 57.32 & 63.60 & 69.51 & 75.17 \\
Weaning rabbit produced (kg/ doe) & 2.752 & 3.021 & 3.244 & 3.329 \\
Selling price (L.E.)** & 96.33 & 105.73 & 113.53 & 116.50 \\
Net revenue (L.E.) & 39.01 & 42.13 & 44.02 & 41.33 \\
Relative revenue (\%) & 100 & 108 & 113 & 106 \\
\hline
\end{tabular}

- Mortality (\%) and management are fixed.

- Ingredients price (L.E. per ton) at 2018 were: 4000 barley; 3000 berseem hay; 4000 wheat bran ; 7000 soybean meal (44\%) ; 7000 Gum Arabic ; 500 limestone ; 9000 premix ; 80000 methionine ; 1000 Di-calcium phosphate ; 20000 anti-fungi; 20000 anti-oxidant; 1000 salt.

- Adding 200 L.E. /ton for pelliting.

* Total feed intake $=($ Pregnant does daily feed intake x 30$)+($ Lactating does daily feed intake x 30) $+($ Pups daily feed intake $\mathrm{x}$ 9)

** Live body weight $35 \mathrm{~L} . \mathrm{E} / \mathrm{kg}$.

\section{Conclusion}

Conclusively, the present study suggested that dietary supplementation of Gum Arabic in rabbit does significantly improved productive and reproductive performance of rabbits does during pregnancy and lactation periods and minimal mortality of kits. Therefore, it could be recommended providing rabbit does diet with Gum Arabic up to 1\% is advisable under Egyptian environmental conditions.

\section{References}

Abd-Razig, N.M., Sabahelkhier, M.K. and Idris, O.F. (2010) Effect of Gum Arabic (Acacia sengal) on lipid profile and performance of laying Hens. $J$. of App. Biosci., 32, 2002 - 2007.

Ali, A.A., Ali, K.E., Fadlalla, A. and Khalid, K.E. (2008) The effects of G.A. oral treatment on the metabolic profile of chronic renal failure patients under regular haemodialysis in Central Sudan. Nat. Prod. Res., 22, 12-21. 
Ali, B.H., Ziada, A. and Blunden, G. (2009) Biological effects of gum arabic: a review of some recent research. Food Chem. Toxicol., 47, 1-8.

Amber, Kh., Abd El-Nabi, Fatma. M., Morsy, A.W. and Morsy, Shama H.A. (2017) Gum Arabic as prebiotic in growing rabbits diet. Glob. Vet., 19, 465-471.

Amber, Kh, Eid, Y.Z., Azoz, A.A. and El-Gebaly, M.M. (2018) Effect of stocking density and dietary phytobiotics on growth performance in rabbit during summer season. J. Sus. Agric. Sci., 44 (1), 13-20.

Ashour, A. F., Badwi, Y.K. and Abd El-Karim, Ragaa E. (2016) Evaluating performance of three rabbit genotypes under egyptian conditions. J. Agric. Res. Kafr El-Sheikh Univ., 42 (2), 115-128.

De Blas, J.C. and Mateos, G.G. (1998) Feed Formulation. In: De Blas C., Wiseman J. (Eds). The Nutrition of the Rabbit. CABI Publishing. CAB International, Wallingford Oxon, UK, 241-253.

Duncan, D.B. (1955) Multiple range and multiple F. tests. Biometrics, 11, 1-42.

El-Khier, M.K.S., Ishag, A.E.K., Abu Elgasim, A., Yagoub, A.A. and Abu Baker (2010) Supplementing laying hen diet with Gum Arabic (Acaciasengal). Effect on egg production, shell thickness andyolk content of cholesterol, calcium and phosphorus. Asian J. of Poul. Sci., 4 (3), 143-148.

FAO (1999) Food and Agriculture Organization of the United Nations. Gum Arabic. Food and Nutrition Paper, No. 52, addendum 7.

Fortun-Lamothe, L., Gidenne, T., Lapanouse, A. and De Dapper, J. (2000) Technical note: an original system to separately control litter and female feed intake without modification of the mother-young relations. World Rabbit Sci., 8, 177-180.

Fouda, Sara F. and Ismail, Rehab S.A.F. (2018) Is Arabic Gum supplementation as a natural antioxidant useful in improving reproductive performance and antioxidant capacity of heat stressed rabbit does in Egypt? Egypt. J. Nut. and Feeds, 21 (3), 701-716.

Gamal El-Din, A.M., Mostafa, A.M., Al-Shabanah, O.A., Al-Bekairi, A.M. and Nagi, M.N. (2003) Protective effect of arabic gum against acetaminophen-induced hepatotoxicity in mice. Pharma. Res., 48, 631-635.

Lebas, F. (1984) Effect de la simultaneite de la lactation et de la gestation sur les performance laitieres chez la lapine. Annales de Zootechnie, 21, 185-191.
Lebas, F., Coudert, P., De Rochambeau, H. and Thébault, R.G. (1997) The Rabbit Husbandry, Health and Production. Food and Agriculture Organization of the United Nations, FAO, Rome, Italy.

Maertens, L., Vanacker, J. and De Coninck, J. (2006) Milk yield and milk composition of 2 commercial hybrids and a selected strain fed a high- energy lactation diet. Proc. $18^{\text {th }}$ Hungarian Conference on Rabbit Production, Kaposvar 24 May 2006, pp. 35-41.

Osman, M.E. (1993) Fractionation and characterization of gum from acacia Senegal. $\mathrm{In} \mathrm{PhD}$ thesis inchemistry and applied chemistry. Salford, pp. 11-24.

Parigi-Bini, R., Xiccato, G. and Cinetto, M. (1990) Repartition de l'energie alimentaire chez la lapine non gestante pendant la premiere lactation. In: Proceedings 5èmes Journées de la Recherche Cunicole en France, Paris, Vol. II. Communication 47. ITAVI, Paris, France, pp. 1-8.

Parigi-Bini, R., Xiccato, G. and Cinetto, M. (1991) Utilization and partition of digestible energy in primiparous rabbit does in different physiological stages. Proc. $12^{\text {th }}$ International Symposium on Energy Metabolism, Zurich, pp. 284-287.

Pascual, J.J., Motta, C., Cervera, C., Quevedo, F., Blas, E. and Fernández Carmona, J. (2002) Effect of dietary energy source on the performance and perirenal fat thickness evolution of primiparous rabbit does. Anim. Sci., 75, 267-279.

Prasad, R. and Karim, S.A. (1998) Effect of dietary energy and protein level on performance and digestibility parameters in pregnant and in lactating rabbit does under tropical environment. World Rabbit Sci., 6, 271-276.

Rochambeau, H. (1998) The parental female from the experimental strains of INRA: genetic evolutions and perspectives. Proc. $7^{\text {th }}$ Journ. Rech. Cunicole, Lyon, France, ITAVI Ed., pp. 3-14.

Rommers, J.M., Meijerhof, R., Noordhuizen, J.P.T.M. and Kemp, B. (2001) Effect of different feeding levels during rearing and age at first insemination on body development, body composition and puberty characteristics of rabbit does. World Rabbit Sci., 9, 101-108.

SAS (2003) Statistical Analysis System, User's Guide, Statistics, SAS Institute Carry, North Carolina, USA.

Szendrö, Zs. and Maertens, L. (2001) Maternal effect during pregnancy and lactation in rabbits (a review). Acta Agraria Kaposváriensis, 5 (2), 1-21. 
Tag El-Din, T.H., Awad, A.L. and Eid, O.A.M. (2018) Effect of dietary probiotic and citric acid addition on growth performance, carcass traits and blood parameters in broiler chicks. J. Sus. Agric .Sci., 44 (3), 123-133.

Theilgaard, P., Sanchez, J.P., Pascual, J.J., Friggens, N.C. and Baselga, M. (2007) Effect of body fatness and selection for prolificacy on survival of rabbit does assessed using a cryopreserved control population. Livestock Sci., 103, 65-73.

Verbeken, D., Dierckx, S. and Dewettinck, K. (2003) Exudate gums: occurrence, production andapplications. Appl. Microbiol. Biotechnol., 63, 10-21.

Xiccato, G., Parigi Bini, R., Dalle Zotte, A., Carazzolo,
A. and Cossu, M.E. (1995) Effect of dietary energy level, addition of fat and physiological state on performance and energy balance of lactating and pregnant rabbit does. Anim. Sci., 61, 387-398.

Xiccato, G. (1996) Nutrition of lactating does. Proc. of $6^{\text {th }}$ World Rabbit Congress, Toulouse, Vol. 1, pp. 29-47.

Xiccato, G., Trocino, A., Sartori, A. and Queaque, P.I. (2004) Effect of doe parity order and litter weaning age on the performance and body energy deficit of rabbit does. Livestock Prod. Sci., 85, 239-51.

Xiccato, G., Trocino, A., Boiti, C. and Brecchia, G. (2005) Reproductive rhythm and litter weaning age as they affect rabbit doe performance and body energy balance. Anim. Sci., 81, 289-296. 


\section{انتاج اللبن والأداء الاتتاجى والتناسلي لامهات الأرانب المغذاة على مستويات مختلفة من الصمغ العربي في العليقة}

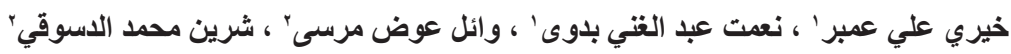

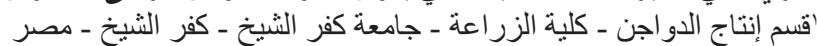

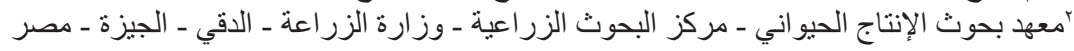

تهدف الدراسة لتحديد ثأثير إضافة الصمغ العربي إلى علائق إناث الأرانب في مر احل فسيولوجية مختلفة على التى التي

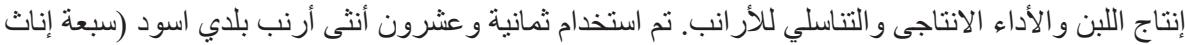

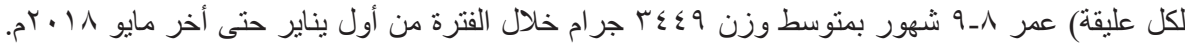

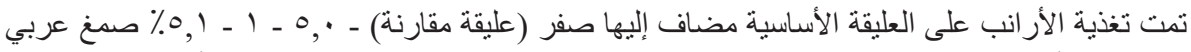

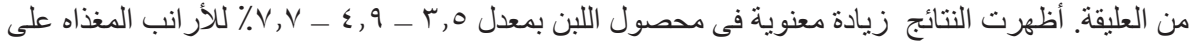

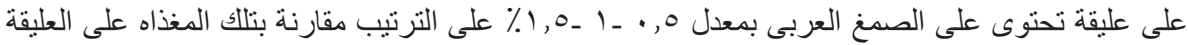

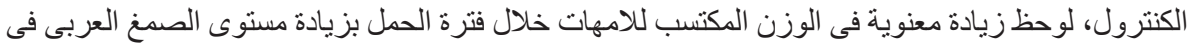

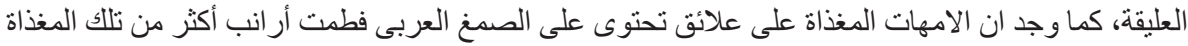

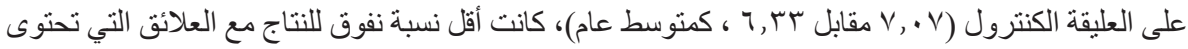

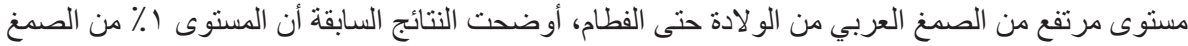

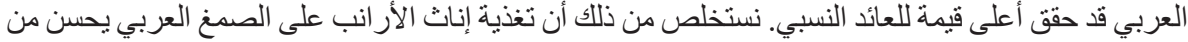

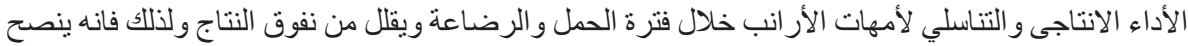

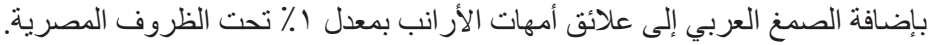

